University of Wollongong

Research Online

Faculty of Social Sciences - Papers (Archive) Faculty of Arts, Social Sciences \& Humanities

$1-1-2002$

Environmental factors associated with adults' participation in physical activity: a review

Nancy Humpel

University of Wollongong, humpel@uow.edu.au

Neville Owen

University of Wollongong

Eva Leslie

University of Wollongong

Follow this and additional works at: https://ro.uow.edu.au/sspapers

Part of the Education Commons, and the Social and Behavioral Sciences Commons

Research Online is the open access institutional repository for the University of Wollongong. For further information contact the UOW Library: research-pubs@uow.edu.au 


\title{
Environmental factors associated with adults' participation in physical activity: a review
}

\begin{abstract}
Background: Promoting physical activity is a public health priority, and changes in the environmental contexts of adults' activity choices are believed to be crucial. However, of the factors associated with physical activity, environmental influences are among the least understood. Method: Using journal scans and computerized literature database searches, we identified 19 quantitative studies that assessed the relationships with physical activity behavior of perceived and objectively determined physical environment attributes. Findings were categorized into those examining five categories: accessibility of facilities, opportunities for activity, weather, safety, and aesthetic attributes. Results: Accessibility, opportunities, and aesthetic attributes had significant associations with physical activity. Weather and safety showed less-strong relationships. Where studies pooled different categories to create composite variables, the associations were less likely to be statistically significant. Conclusions: Physical environment factors have consistent associations with physical activity behavior. Further development of ecologic and environmental models, together with behaviorspecific and context-specific measurement strategies, should help in further understanding of these associations. Prospective studies are required to identify possible causal relationships.
\end{abstract}

\section{Keywords}

physical, review, environmental, adults, factors, activity, participation, associated

\section{Disciplines}

Education | Social and Behavioral Sciences

\section{Publication Details}

Humpel, N., Owen, N. \& Leslie, E. (2002). Environmental factors associated with adults' participation in physical activity: a review. American Journal of Preventative Medicine, 22 (3), 188-199. 


\title{
Environmental factors associated with adults' participation in physical activity: A review
}

Nancy Humpel, Neville Owen, Eva Leslie

Faculty of Health and Behavioural Sciences, University of Wollongong, Wollongong, New South Wales, Australia

\begin{abstract}
Background: Promoting physical activity is a public health priority, and changes in the environmental contexts of adults' activity choices are believed to be crucial. However, of the factors associated with physical activity, environmental influences are among the least understood.
\end{abstract}

Method: Using journal scans and computerized literature database searches, we identified 19 quantitative studies that assessed the relationships with physical activity behavior of perceived and objectively determined physical environment attributes. Findings were categorized into those examining five categories: accessibility of facilities, opportunities for activity, weather, safety, and aesthetic attributes.

Results: Accessibility, opportunities, and aesthetic attributes had significant associations with physical activity. Weather and safety showed less-strong relationships. Where studies pooled different categories to create composite variables, the associations were less likely to be statistically significant.

Conclusions: Physical environment factors have consistent associations with physical activity behavior. Further development of ecologic and environmental models, together with behavior-specific and contextspecific measurement strategies, should help in further understanding of these associations. Prospective studies are required to identify possible causal relationships.

Keywords: environment; exercise; preventive medicine and public health; public facilities; public policy 


\section{Introductions}

Regular physical activity is strongly associated with better physical and psychological health outcomes, and the promotion of physical activity is now a high public health priority. ${ }^{1}$ To develop relevant policies and effective interventions, it is necessary to identify the factors that can be changed to influence physical activity behavior. ${ }^{2}$ Such factors have been classified within seven domains: demographic and biological, psychological, cognitive and emotional, behavioral attributes and skills, social and cultural, physical environmental, and physical activity characteristics (perceived effort and intensity). ${ }^{2}$ and ${ }^{3}$ Within these classes of factors, physical environment attributes are a new topic of research interest ${ }^{4}$ and are being addressed by policymakers and program providers. ${ }^{5}$ However, environmental attributes are among the least understood of the known influences on physical activity. Their conceptualization and measurement comprise a relatively new area of research. ${ }^{5,6}$

Applications of health behavior theories to physical activity have identified roles for environmental influences, most often in terms of "barriers," "facilitating conditions," or "contextual influences.," Bandura's ${ }^{8}$ social cognitive theory provides an account of the interactions of environmental, personal, and behavioral factors. The relative influence exerted by these three sets of interacting factors varies for different activities, different individuals, and different circumstances. Bandura argues that when environmental attributes exercise powerful constraints on behavior, they emerge as the over-riding determinants. Environmental attributes, in the case of physical activity, may be particularly influential.

Sallis and Hovell ${ }^{9}$ developed a social cognitive model of physical activity behavior, emphasizing the role of environmental attributes, within a context where multiple determinants interact at several levels.

"Ecological" models of health behavior provide accounts of the interaction of people with multiple levels of determinants within their physical and sociocultural environments. ${ }^{10,11}$ Given the inherent complexities of ecologic frameworks, behavior-specific models have been proposed. ${ }^{4,6}$ Applied to physical activity, ${ }^{4,5}$ such models aim to provide an integrated account of the complex patterns of possible determinants.

A central focus of ecologic models is the role of the physical environment, recognizing that environments themselves and people's behavior within them are shaped by social and organizational influences. In this regard, the "behavior settings" construct ${ }^{12}$ is helpful, highlighting how physical activity can be promoted or encouraged within some environments, while made more difficult or restricted in others. ${ }^{4,6}$ Conceptual models to account for the influence of environmental factors on physical activity should be particularly helpful in the new public health context for physical activity, within which environmental and policy interventions are being developed and implemented. ${ }^{5,13}$

In new and emerging fields of preventive medicine and public health, models that help to explain behaviorenvironment relationships can play a key role in shaping the research agenda and in linking research, policy, and practice. However, in order to assess the utility of these models, the key dimensions that they identify must be measurable. While the measurement of physical activity behavior is now a well-established field, this is not the case for the measurement of physical activity environments. ${ }^{4,5}$ Given the rapidly developing focus in research, public policy, and practice on the role of environmental attributes in determining physical activity participation, there is the need for high-quality empirical evidence supporting environment-behavior relationships. In this context, there is a particular need to examine how environmental factors that may influence physical activity can best be assessed.

We reviewed the findings of quantitative studies examining the associations of particular environmental attributes with physical activity behaviors. Our focus was on studies of adults. Our aim was to provide a systematic overview of the measures that have been used to assess environmental attributes and to review the patterns of environment-behavior associations that have thus far been identified. 


\section{Methods}

Our primary inclusion criterion was relationships between particular physical environment attributes and physical activity behaviors. Only studies that assessed some physical activity behavior or behaviors as an outcome variable or variables were included. Specific items within the assessment instruments from each study that related to the physical environment were, where possible, extracted for the purposes of this review. If a theory or construct was mentioned as guiding the study, this was noted. The specific type of physical activity behavior measured in each study was identified and, if available, the specific setting in which the behavior occurred.

Computerized searches of Psychinfo, Medline, and Cinahl were conducted in the English-language literature, using the following search terms: physical activity, exercise, environment, environmental determinants, physical environment, facilities, convenience, barriers, constraints, recreation, behavioral context, inactivity, situational factors, neighborhood, recreation, and safety.

Studies initially identified by using the search criteria totaled 33. Studies were excluded from further consideration if they were qualitative only; if they were solely descriptive in nature (e.g., reporting only frequencies of an environmental barrier); or if the physical environment items (perceived and objective) of the study could not be disentangled from psychological or social barrier items (primarily cases in which only composite scores were reported). Only those studies that measured environmental variables that could be related individually and directly to measured physical activity variables were retained. An exception was made for cases in which a small number of items assessing closely related attributes were combined; the derived variable was included in our review.

The items dealing with environmental attributes that were extracted from the papers identified in our searches were categorized by logically plausible groupings of similar items. At this early stage of research on the associations of environmental attributes with physical activity behavior, this is most appropriately a descriptive integration, rather than a theoretically based synthesis. Social cognitive theory and ecologic models point to environmental factors as potentially important influences on health-related behaviors. However, measures of environmental attributes can be seen as reflecting, only in a very broad sense, the "environmental" construct within these conceptual models. Thus, we did not attempt, formally and specifically, to identify links of the environmental variables that were measured in the studies with particular theories or specific constructs. Where studies did identify a theoretical basis or bases for their approach, this is noted in the narrative text accompanying our tables. 


\section{Results}

Using the above criteria, we identified 19 studies, of which 16 examined the relationship between the perceived physical environments and physical activity. ${ }^{14,15,16,17,18,19,20,21,22,23,24,25,26,27,28,29}$ Four of the studies used objective measures of the environment, including place of residence (using postal codes), physical distance, and accessibility of facilities. ${ }^{29,30,31,32}$ One study included both perceived and objective measures. ${ }^{29}$ Twelve of the 19 studies identified an explicit theoretical basis to their research. Only one study ${ }^{14}$ reported prospective data on the relationship of environmental variables to physical activity change.

Some studies assessed perceptions of generally defined "barriers" to starting or increasing physical activity. ${ }^{15,16,17,18}$ Others included barrier items along with items related to the existence and characteristics of physical facilities in the environment, such as the fact that they existed in participants' neighborhood or home environment or that such facilities were conveniently located. ${ }^{18,19,20,21,22,23,24,29}$

\section{Studies using self-report measures of environmental attributes}

Table 1 presents the final selection of quantitative studies examining the relationship between self-report environmental factors and physical activity among adults. For each paper, the environmental items are reported along with the scale used. The type of physical activity behavior measured (and in parentheses, the specific outcome variable used in the analysis where that was different from the behavior measured) is listed. Where reported, the setting of the study is described.

Table 1. Characteristics and main findings of studies examining relationships between perceived environmental attributes and physical activity among adults

\begin{tabular}{|c|c|c|c|c|c|c|c|}
\hline Reference & $\begin{array}{c}\text { Number/ } \\
\text { age/ } \\
\text { gender }\end{array}$ & $\mid \begin{array}{c}\text { Environmental } \\
\text { variable }\end{array}$ & Scale & Setting & $\begin{array}{c}\text { Physical activity } \\
\text { behavior (main } \\
\text { outcome variable) }\end{array}$ & $\mid \begin{array}{c}\text { Statistical } \\
\text { adjustment }\end{array}$ & $\begin{array}{c}\text { Significant } \\
\text { associations with } \\
\text { main outcome } \\
\text { variable } \\
\end{array}$ \\
\hline $\begin{array}{l}\text { Ball et al. } \\
(2001) 23\end{array}$ & $\begin{array}{l}\mathrm{N}=3392 \\
\text { Adult } \\
\mathrm{M}=46 \%\end{array}$ & \begin{tabular}{|l|} 
Your \\
neighborhood is \\
friendly You \\
find it pleasant \\
near your home \\
Your local area \\
is attractive A \\
park or beach is \\
within walking \\
distance A cycle \\
path is \\
accessible Shops \\
are in walking \\
distance.
\end{tabular} & Likert (1-5) & $\begin{array}{l}\text { Community } \\
\text { open space }\end{array}$ & $\begin{array}{l}\text { Walking for exercise } \\
\text { (walking/ not } \\
\text { walking) }\end{array}$ & A, S, E & $\begin{array}{l}\text { Less aesthetic and less } \\
\text { convenient } \\
\text { environment associated } \\
\text { with not walking }\end{array}$ \\
\hline $\begin{array}{l}\text { Booth et } \\
\text { al. } \\
(2000) 22\end{array}$ & $\begin{array}{l}\mathrm{N}=2374 \\
\geq 60 \text { years } \\
\mathrm{M}+\mathrm{F}\end{array}$ & \begin{tabular}{|l|} 
Have you any \\
exercise \\
equipment at \\
home (e.g., \\
exercise bike, \\
swimming pool, \\
exercise video)? \\
How safe do you \\
feel walking \\
during the day? \\
Footpaths
\end{tabular} & |Yes/no & $\begin{array}{l}\text { Home } \\
\text { community }\end{array}$ & $\begin{array}{l}\text { Vigorous activities } \\
\text { Walking for } \\
\text { exercise, leisure, or } \\
\text { recreation Moderate } \\
\text { activities } \\
\text { (activity/inactive) }\end{array}$ & $A, S$ & $\begin{array}{l}\text { Footpaths safe for } \\
\text { walking and access to } \\
\text { local facilities } \\
\text { associated with being } \\
\text { active }\end{array}$ \\
\hline
\end{tabular}




\begin{tabular}{|c|c|c|c|c|c|c|c|}
\hline Reference & $\mid \begin{array}{c}\text { Number } / \\
\text { age/ } \\
\text { gender }\end{array}$ & $\begin{array}{c}\text { Environmental } \\
\text { variable }\end{array}$ & Scale & Setting & $\begin{array}{c}\text { Physical activity } \\
\text { behavior (main } \\
\text { outcome variable) }\end{array}$ & $\| \begin{array}{c}\text { Statistical } \\
\text { adjustment }\end{array}$ & $\begin{array}{c}\text { Significant } \\
\text { associations with } \\
\text { main outcome } \\
\text { variable }\end{array}$ \\
\hline & & $\begin{array}{l}\text { perceived as safe } \\
\text { for walking. } \\
\text { Accesses to } \\
\text { facilities that } \\
\text { may be used for } \\
\text { activity (e.g., } \\
\text { recreation enter, } \\
\text { cycle path, golf } \\
\text { course, gym, } \\
\text { park). }\end{array}$ & & & & & \\
\hline $\begin{array}{l}\text { CDC } \\
(1999) 27\end{array}$ & $\mid \begin{array}{l}\mathrm{N}=12,767 \\
\geq 18 \text { years } \\
\mathrm{M}+\mathrm{F}\end{array}$ & $\begin{array}{l}\text { How safe from } \\
\text { crime is your } \\
\text { neighborhood? }\end{array}$ & Likert (1-4) & $\mid \begin{array}{l}\text { Not } \\
\text { identified }\end{array}$ & $\begin{array}{l}\text { Walking/moderate } \\
\text { activity Vigorous } \\
\text { activity (active/ } \\
\text { inactive) }\end{array}$ & E, R & $\begin{array}{l}\text { Unsafe neighborhood } \\
\text { associated with being } \\
\text { inactive }\end{array}$ \\
\hline $\begin{array}{l}\text { Hovell et } \\
\text { al. } \\
(1989) 25\end{array}$ & $\begin{array}{l}\mathrm{N}=2053 \\
\text { Adults } \\
\mathrm{M}+\mathrm{F}\end{array}$ & \begin{tabular}{|l} 
Home \\
equipment \\
Number of \\
facilities \\
perceived as \\
convenient \\
Neighborhood \\
environment
\end{tabular} & $\begin{array}{l}\text { Rated } \\
\text { frequency }\end{array}$ & $\mid \begin{array}{l}\text { Not } \\
\text { identified }\end{array}$ & Walking for exercise & $\mathrm{A}, \mathrm{S}, \mathrm{E}$ & $\begin{array}{l}\text { Neighborhood } \\
\text { environment weak } \\
\text { association with } \\
\text { walking }\end{array}$ \\
\hline $\begin{array}{l}\text { Jakicic et } \\
\text { al. } \\
(1997) 26\end{array}$ & $\left|\begin{array}{l}\mathrm{N}=194 \\
27-45 \mathrm{yrs} \\
\mathrm{M}+\mathrm{F}\end{array}\right|$ & $\begin{array}{l}\text { What types of } \\
\text { sport, } \\
\text { recreational, and } \\
\text { exercise } \\
\text { equipment do } \\
\text { you have at } \\
\text { home (14 } \\
\text { types)? }\end{array}$ & $\begin{array}{l}\text { Present/not } \\
\text { present }\end{array}$ & & $\mid \begin{array}{l}\text { Walking/stairs Sport } \\
\text { and recreation } \\
\text { activity } \\
\text { (heavy/moderate/light/ } \\
\text { blocks/flights/total) }\end{array}$ & A, NI & $\begin{array}{l}\text { Total equipment } \\
\text { association with heavy, } \\
\text { moderate, and total } \\
\text { activity }\end{array}$ \\
\hline $\begin{array}{l}\text { King et al. } \\
(2000) 18\end{array}$ & $\begin{array}{l}\mathrm{N}=2912 \\
>40 \text { years } \\
\text { F only }\end{array}$ & \begin{tabular}{|l} 
Sidewalks \\
Heavy traffic \\
Hills Streetlights \\
Unattended dogs \\
Enjoyable \\
scenery High \\
levels of crime \\
How safe is it to \\
walk or jog \\
alone during the \\
day? Lack a safe \\
place to exercise \\
Poor weather
\end{tabular} & $\left|\begin{array}{l}\text { Present/not } \\
\text { present } \\
\text { Likert (1-5) }\end{array}\right|$ & \begin{tabular}{|l} 
Leisure \\
time, \\
household, \\
occupation
\end{tabular} & \begin{tabular}{|} 
Moderate activity \\
Vigorous activity \\
(active/sedentary)
\end{tabular} & A, E, MS, L & $\begin{array}{l}\text { Hills, unattended dogs, } \\
\text { enjoyable scenery } \\
\text { associated with being } \\
\text { active }\end{array}$ \\
\hline $\begin{array}{l}\text { Leslie et } \\
\text { al. } \\
(1999) 24\end{array}$ & $\begin{array}{l}\mathrm{N}=2729 \\
15-76 \\
\text { years } \\
\mathrm{M}+\mathrm{F} \\
\mathrm{M}=42 \%\end{array}$ & $\begin{array}{l}\text { Awareness of } \\
\text { campus facilities } \\
\text { Gym } \\
\text { membership }\end{array}$ & Yes/no & $\begin{array}{l}\text { University } \\
\text { campus }\end{array}$ & \begin{tabular}{|l|} 
Walking for \\
recreation and \\
transport Moderate \\
exercise Vigorous \\
exercise \\
(sufficient/insufficient)
\end{tabular} & A & $\begin{array}{l}\text { More awareness } \\
\text { associated with being } \\
\text { sufficiently active }\end{array}$ \\
\hline $\begin{array}{l}\text { MacDouga } \\
11 \text { et al. } \\
(1997) 20\end{array}$ & $\begin{array}{l}\mathrm{N}=1765 \\
\text { Adults } \\
\mathrm{M}+\mathrm{F}\end{array}$ & \begin{tabular}{|l} 
Recreation \\
facilities Living \\
environment
\end{tabular} & Likert (1-4) & $\mid \begin{array}{l}\text { Open space, } \\
\text { sport } \\
\text { facilities }\end{array}$ & \begin{tabular}{|l|} 
Moderate activity \\
Vigorous sport \\
Walking for exercise \\
(moderate
\end{tabular} & $A, E, H$ & $\begin{array}{l}\text { Low rating of facilities } \\
\text { and environment } \\
\text { associated with } \\
\text { inactivity for men only }\end{array}$ \\
\hline
\end{tabular}




\begin{tabular}{|c|c|c|c|c|c|c|c|}
\hline Reference & $\mid \begin{array}{c}\text { Number/ } \\
\text { age/ } \\
\text { gender }\end{array}$ & $\begin{array}{c}\text { Environmental } \\
\text { variable }\end{array}$ & Scale & Setting & $\begin{array}{c}\text { Physical activity } \\
\text { behavior (main } \\
\text { outcome variable) }\end{array}$ & $\| \begin{array}{c}\text { Statistical } \\
\text { adjustment }\end{array}$ & $\begin{array}{c}\text { Significant } \\
\text { associations with } \\
\text { main outcome } \\
\text { variable } \\
\end{array}$ \\
\hline & & & & & active/inactive) & & \\
\hline $\begin{array}{l}\text { Sallis et al. } \\
(1989) 19\end{array} \mid$ & $\begin{array}{l}\mathrm{N}=1789 \\
\text { Adults } \\
\text { M+F }\end{array}$ & \begin{tabular}{|l} 
Lack of \\
equipment Lack \\
of facilities Lack \\
of good weather \\
Home \\
equipment \\
Neighborhood \\
environment \\
Number of \\
facilities \\
perceived as \\
convenient \\
\end{tabular} & $\begin{array}{l}\text { Rated } \\
\text { frequency }\end{array}$ & $\mid \begin{array}{l}\text { Not } \\
\text { identified }\end{array}$ & Vigorous exercise & $\|$ A, S, E & $\begin{array}{l}\text { Home equipment } \\
\text { associated with } \\
\text { vigorous exercise }\end{array}$ \\
\hline $\begin{array}{l}\text { Sallis et al. } \\
(1992) 14 \\
\text { (prospecti } \\
\text { ve study) }\end{array}$ & $\begin{array}{l}\mathrm{N}=1719 \\
18-90 \\
\text { years } \\
\mathrm{M}+\mathrm{F}\end{array}$ & \begin{tabular}{|l} 
Same items as \\
Hovell et al. \\
$(1989) 25$ and \\
Sallis et al. \\
(1989)19
\end{tabular} & $\begin{array}{l}\text { Rated } \\
\text { frequency }\end{array}$ & $\mid \begin{array}{l}\text { Not } \\
\text { identified }\end{array}$ & $\begin{array}{l}\text { Vigorous exercise } \\
\text { (change in vigorous } \\
\text { activity) }\end{array}$ & $\|$ A, E & $\begin{array}{l}\text { Neighborhood } \\
\text { environment associated } \\
\text { with change in } \\
\text { vigorous activity (men) }\end{array}$ \\
\hline$\left|\begin{array}{l}\text { Sallis et al. } \\
(1997) 21\end{array}\right|$ & $\mid \begin{array}{l}\mathrm{N}=110 \\
\text { Mean=20 } \\
6 \text { years } \\
\mathrm{M}=25 \%\end{array}$ & \begin{tabular}{|l} 
Please indicate \\
which items are \\
in your home: \\
15 items (e.g., \\
aerobic \\
equipment, \\
bicycle, dog, \\
trampoline) \\
Which apply to \\
neighborhood? \\
Sidewalks, \\
heavy traffic, \\
hills, \\
streetlights, dogs \\
unattended, \\
enjoyable \\
scenery, crime \\
Rate your \\
neighborhood as \\
residential, \\
commercial, or \\
mixed How safe \\
do you feel \\
walking during \\
the day? For \\
each of 18 \\
places you can \\
exercise, \\
indicate if it is \\
on a frequently \\
traveled route \\
e.g., aerobic \\
studio, \\
basketball court, \\
beach) \\
\end{tabular} & \begin{tabular}{||l||} 
Yes/no \\
Yes/no \\
Likert (1-5) \\
Yes/no
\end{tabular} & $\mid \begin{array}{l}\text { Home } \\
\text { community }\end{array}$ & \begin{tabular}{|l} 
Walking for exercise \\
Strength exercise \\
Vigorous exercise
\end{tabular} & $\begin{array}{l}\text { A, S, R, } \\
\text { SES }\end{array}$ & $\begin{array}{l}\text { Home equipment } \\
\text { associated with } \\
\text { strength building } \\
\text { exercise }\end{array}$ \\
\hline Shaw et al. & $\mathrm{N}=14,674$ & No facilities & Present/abse & Not & Vigorous sport & None & No facilities associated \\
\hline
\end{tabular}




\begin{tabular}{|c|c|c|c|c|c|c|c|}
\hline Reference & $\mid \begin{array}{c}\text { Number/ } \\
\text { age/ } \\
\text { gender }\end{array}$ & $\mid \begin{array}{c}\text { Environmental } \\
\text { variable }\end{array}$ & Scale & Setting & $\begin{array}{c}\text { Physical activity } \\
\text { behavior (main } \\
\text { outcome variable) }\end{array}$ & $\mid \begin{array}{c}\text { Statistical } \\
\text { adjustment }\end{array}$ & $\begin{array}{c}\text { Significant } \\
\text { associations with } \\
\text { main outcome } \\
\text { variable } \\
\end{array}$ \\
\hline (1991)16 & $\begin{array}{l}18-69 \\
\text { years } \\
\mathrm{M}+\mathrm{F}\end{array}$ & $\begin{array}{l}\text { nearby } \\
\text { Available } \\
\text { facilities are } \\
\text { inadequate }\end{array}$ & nt & identified & \begin{tabular}{|l|} 
Moderate recreation \\
Walking for exercise \\
Cycling for exercise \\
(participation/no \\
participation)
\end{tabular} & reported & \begin{tabular}{|l} 
with more participation \\
(women only). \\
Inadequate facilities \\
associated with more \\
participation
\end{tabular} \\
\hline $\begin{array}{l}\text { Stahl et al. } \\
(2001) 28\end{array} \mid$ & $\begin{array}{l}\mathrm{N}=3342 \\
\geq 18 \text { years } \\
\mathrm{M}=43 \%\end{array}$ & \begin{tabular}{|l} 
My area offers \\
many \\
opportunities to \\
be active Local \\
clubs and other \\
providers offer \\
many \\
opportunities \\
\end{tabular} & Likert (1-5) & $\mid \begin{array}{l}\text { Not } \\
\text { identified }\end{array}$ & $\begin{array}{l}\text { Total activity } \\
\text { (active/inactive) }\end{array}$ & A, S, E & $\begin{array}{l}\text { More awareness of } \\
\text { opportunities for } \\
\text { activity associated with } \\
\text { more activity }\end{array}$ \\
\hline $\begin{array}{l}\text { Sternfeld } \\
\text { et al. } \\
(1999) 15\end{array}$ & \begin{tabular}{|l}
$\mathrm{N}=5000$ \\
$20-65$ \\
years F \\
only \\
\end{tabular} & $\mid \begin{array}{l}\text { Lack of } \\
\text { equipment Lack } \\
\text { of facilities }\end{array}$ & Likert (1-5) & \begin{tabular}{|l|} 
Occupation \\
al, home \\
Leisure \\
time
\end{tabular} & \begin{tabular}{|l|} 
Occupational activity \\
Household activity \\
Sport and exercise \\
Active living \\
\end{tabular} & $\| A, E, R, C$ & \begin{tabular}{|l} 
Lack of equipment and \\
facilities negatively \\
associated with sport \\
and exercise
\end{tabular} \\
\hline $\begin{array}{l}\text { Troped et } \\
\text { al. } \\
(2001) 29\end{array}$ & \begin{tabular}{|l}
$\mathrm{N}=413$ \\
Mean=51 \\
years \\
$\mathrm{M}+\mathrm{F}$ \\
$\mathrm{M}=40 \%$
\end{tabular} & \begin{tabular}{|l} 
Which of the \\
following apply \\
to your \\
neighborhood: \\
sidewalks, heavy \\
traffic, hills, \\
enjoyable \\
scenery? Rate \\
your \\
neighborhood as \\
residential, \\
mostly \\
commerical, or \\
mixed. How safe \\
do you feel \\
walking during \\
the day? \\
Perceived \\
distance from \\
bikeway \\
Negotiate a \\
steep hill on the \\
way to the \\
bikeway Cross a \\
busy street to \\
access the \\
bikeway
\end{tabular} & \begin{tabular}{l||} 
Yes/no \\
Likert (1-5) \\
$1 / 4$ mile \\
Yes/no \\
Yes/no
\end{tabular} & $\mid \begin{array}{l}\text { Community } \\
\text { open space, } \\
\text { neighborhood }\end{array}$ & $\begin{array}{l}\text { (use/nonuse of } \\
\text { bikeway) }\end{array}$ & A, S & $\mid \begin{array}{l}\text { Greater reported } \\
\text { distance associated } \\
\text { with less use. No busy } \\
\text { street to cross } \\
\text { associated with more } \\
\text { use. Residential } \\
\text { neighborhood } \\
\text { (unadjusted analysis) } \\
\text { associated with nonuse }\end{array}$ \\
\hline $\begin{array}{l}\text { Wilcox et } \\
\text { al. } \\
(2000) 17\end{array}$ & $\begin{array}{l}\mathrm{N}=2912 \\
\geq 40 \text { years } \\
\text { F only }\end{array}$ & \begin{tabular}{|l|} 
Sidewalks \\
Heavy traffic \\
Hills Streetlights \\
Unattended dogs \\
Enjoyable \\
scenery High \\
levels of crime \\
Easy access to \\
walking trails, \\
swimming pool \\
\end{tabular} & $\begin{array}{l}\text { Present/abse } \\
\text { nt Likert } \\
(1-5)\end{array}$ & \begin{tabular}{|l|} 
Leisure \\
time \\
Household \\
Occupational
\end{tabular} & \begin{tabular}{|l} 
Moderate activity \\
Vigorous activity \\
(active/ sedentary)
\end{tabular} & ${ }_{\text {L }}^{\text {A }, ~ S, ~ E, ~ R, ~}$ & $\begin{array}{l}\text { Lack of scenery } \\
\text { associated with being } \\
\text { sedentary in rural } \\
\text { women }\end{array}$ \\
\hline
\end{tabular}




\begin{tabular}{|c|c|c|c|c|c|c|c|}
\hline Reference & $\begin{array}{c}\text { Number/ } \\
\text { age/ } \\
\text { gender }\end{array}$ & $\begin{array}{c}\text { Environmental } \\
\text { variable }\end{array}$ & Scale & Setting & $\begin{array}{c}\text { Physical activity } \\
\text { behavior (main } \\
\text { outcome variable) }\end{array}$ & $\begin{array}{c}\text { Statistical } \\
\text { adjustment }\end{array}$ & $\begin{array}{c}\text { Significant } \\
\text { associations with } \\
\text { main outcome } \\
\text { variable } \\
\end{array}$ \\
\hline & & \begin{tabular}{|l} 
Lack a safe \\
place to exercise \\
Poor weather
\end{tabular} & & & & & \\
\hline
\end{tabular}

A, age; C, children; CDC, Centers for Disease Control and Prevention; E, education; F, female; H, health status; L, location; M, male; MS, marital status; NI, number of individuals at home; R, race; S, sex; SES, socioeconomic status.

The earliest self-report study identified (reported by Sallis et al. ${ }^{19}$ in 1989) examined the cross-sectional relationships of variables reflecting constructs from social learning theory (self-efficacy, modeling, and family and friend support and barriers) with vigorous exercise. Items that formed a "neighborhood environment" variable were included in their study (safety and ease of exercising in the neighborhood and frequently seeing others exercise). This variable did not emerge as a barrier to vigorous exercise. Neighborhood environment and convenience of facilities were not significantly associated with reported vigorous exercise (see Table 1). The strongest association with vigorous exercise in adjusted analysis was having home exercise equipment. A second study using the same items and participants ${ }^{25}$ showed a weak association of "neighborhood environment" with walking for exercise. A subsequent prospective study with the same participants ${ }^{14}$ found neighborhood environment, convenience of facilities, and home equipment to be predictors of change in vigorous activity over 24 months in men only. In adjusted multivariate analysis, neighborhood environment was the only significant predictor (and negatively so) of change in vigorous activity for men.

Aspects of the physical environment such as "convenience of facilities" or "lack of facilities" are items that were frequently used in these self-report studies. For example, Sallis et al. ${ }^{21}$ found home equipment to be associated with doing strength-building exercises, and Booth et al. ${ }^{22}$ found accessibility of local facilities to be positively associated with older adults being categorized as sufficiently physically active in their leisure time for health benefits.

Sallis et al. ${ }^{21}$ used an explicitly identified ecologic model to develop 43 items to assess physical environment variables in college students. This study assessed the behavior settings of homes and neighborhoods, as well as the convenience of 18 physical activity facilities (whether they were on a frequently traveled route). Presence of home equipment was associated with strength-building and vigorous exercise, and convenient facilities were associated with strength-building exercise. In adjusted multivariate analysis, only home equipment was significantly associated with strength-building exercise.

Booth et al. ${ }^{22}$ attempted to identify social cognitive and perceived environmental influences associated with physical activity in older adults. They used constructs from social cognitive theory, the theory of planned behavior, and ecologic models to inform the measurement aspects of their study. In a multivariate analysis, reported access to a park and perceiving footpaths as safe for walking were significantly associated with being categorized as sufficiently physically active for health benefits.

Sallis et al. ${ }^{21}$ also examined perceptions of the qualitative aspects (aesthetics) of neighborhoods. They found that a neighborhood environment scale, which comprised three separate components (neighborhood features, perceived safety, and neighborhood character), was not related to any measure of physical activity. They hypothesized that the lack of association may have been because if the neighborhood is not perceived safe, convenient, and enjoyable for physical activity, then people may be active in other environments, away from 
the local neighborhood. Another explanation could be that the composite outcome measure used in this study may have obscured associations that would be evidenced if items were examined individually.

Ball et al. ${ }^{23}$ used a social-ecologic framework in examining relationships of seven environmental variables with reported walking for exercise. Items were grouped as perceptions of the "aesthetic nature of the environment" (three items), the "convenience of the environment" (three items), and social environment for walking (one item). Walking for exercise data were dichotomized into "any" or "no" reported walking in last 2 weeks. Those reporting a less aesthetically pleasing and less convenient environment were less likely to report walking.

King et al. ${ }^{18}$ examined the same neighborhood variables as Sallis et al. ${ }^{21}$ as well as a number of specific barriers in a sample of women aged $>40$ years. The outcome variable was dichotomous-active or sedentary. The two environmental barriers identified (lack of a safe place to exercise and poor weather) were not related to being active. The neighborhood characteristics of hills, enjoyable scenery, and unattended dogs were found to be significantly associated with physical activity.

A study by Sternfeld et al. ${ }^{15}$ on the physical activity patterns of ethnically diverse women aged 20 to 65 years examined occupational, sports and exercise, active living (recreational), and household/caregiving physical activities. They found that the correlates of physical activity vary by the domain under which the behavior occurs. The environmental items (lack of equipment and facilities) were significantly related only to sport and exercise activity.

\section{Studies using objectively assessed environmental measures}

Table 2 summarizes the methods and findings of studies that examined objectively assessed environmental factors. The physical activity behavior measured, the outcome variable, and the behavior setting are presented if reported.

Table 2. Characteristics and main findings of cross-sectional studies using objectively assessed environmental attributes of physical activity among adults

\begin{tabular}{|c|c|c|c|c|c|c|c|}
\hline Reference & Number/age/gender & $\mid \begin{array}{c}\text { Environmental } \\
\text { variable }\end{array}$ & Scale & Setting & $\begin{array}{l}\text { Physical } \\
\text { activity } \\
\text { behavior } \\
\text { (main } \\
\text { outcome } \\
\text { variable) }\end{array}$ & $\begin{array}{c}\text { Statistical } \\
\text { adjustment }\end{array}$ & $\mid \begin{array}{c}\text { Significant } \\
\text { associations } \\
\text { with main } \\
\text { outcome } \\
\text { variable }\end{array}$ \\
\hline $\begin{array}{l}\text { Bauman et } \\
\text { al. }(1999)^{30}\end{array}$ & $\begin{array}{l}\mathrm{N}=16,177 \text { Adults } \\
\mathrm{M}=42 \%\end{array}$ & $\| \begin{array}{l}\text { Place of } \\
\text { residence }\end{array}$ & Inland/coastal & Not identified & $\left|\begin{array}{|l}\text { Walking } \\
\text { Moderate } \\
\text { activity } \\
\text { Vigorous } \\
\text { activity } \\
\text { (sedentary/ } \\
\text { adequate/high) }\end{array}\right|$ & \begin{tabular}{|l} 
A, S, E, \\
Em, B
\end{tabular} & $\begin{array}{l}\text { Coastal } \\
\text { residence } \\
\text { associated } \\
\text { with } \\
\text { adequate } \\
\text { high, and } \\
\text { negatively } \\
\text { with } \\
\text { sedentary }\end{array}$ \\
\hline $\begin{array}{l}\text { Giles-Corti } \\
\text { and Donovan } \\
\text { (in press) }^{32}\end{array}$ & $\begin{array}{l}\mathrm{N}=1803 \\
\mathrm{M}+\mathrm{F}\end{array}$ & \begin{tabular}{|l|} 
Functional \\
(footpath/shop) \\
Appeal \\
(traffic/trees) \\
Access to built \\
facilities \\
Access to
\end{tabular} & \begin{tabular}{|l} 
Present/absent \\
Distance \\
Distance
\end{tabular} & \begin{tabular}{|l||} 
Community \\
open space \\
Neighborhood \\
Built facilities
\end{tabular} & \begin{tabular}{|l|l|} 
Walking \\
Moderate \\
activity \\
Vigorous \\
activity \\
(exercising 30 \\
minute most
\end{tabular} & $\begin{array}{l}\text { A, S, C, I } \\
\text { Em }\end{array}$ & \begin{tabular}{|l|} 
No \\
association \\
of the four \\
variables \\
individually \\
with \\
exercising.
\end{tabular} \\
\hline
\end{tabular}




\begin{tabular}{|c|c|c|c|c|c|c|c|}
\hline Reference & Number/age/gender & $\mid \begin{array}{c}\text { Environmental } \\
\text { variable }\end{array}$ & Scale & Setting & $\begin{array}{c}\text { Physical } \\
\text { activity } \\
\text { behavior } \\
\text { (main } \\
\text { outcome } \\
\text { variable) } \\
\end{array}$ & $\begin{array}{c}\text { Statistical } \\
\text { adjustment }\end{array}$ & $\begin{array}{c}\text { Significant } \\
\text { associations } \\
\text { with main } \\
\text { outcome } \\
\text { variable }\end{array}$ \\
\hline & & \begin{tabular}{|l} 
natural \\
facilities $^{\mathrm{a}}$
\end{tabular} & & & days) & & \begin{tabular}{|l} 
Composite \\
score \\
associated \\
with \\
exercising \\
30 minute \\
most days \\
\end{tabular} \\
\hline $\begin{array}{l}\text { Sallis et al. } \\
(1990)^{31}\end{array}$ & $\begin{array}{l}N=2053 \text { Mean }=48 \text { years } \\
M+F \quad M=58 \%\end{array}$ & $\begin{array}{l}\text { Density of pay } \\
\text { and free } \\
\text { facilities }\end{array}$ & On grid-map & Not identified & $\mid$\begin{tabular}{|l} 
Vigorous \\
activity \\
(sedentary/ \\
exerciser)
\end{tabular} & A, E, I & \begin{tabular}{|l} 
Greater \\
density of \\
pay \\
facilities \\
associated \\
with \\
exerciser \\
\end{tabular} \\
\hline $\begin{array}{l}\text { Troped et al. } \\
(2001)^{29}\end{array}$ & $\begin{array}{l}N=413 \text { Mean }=51 \text { years } \\
M+F \quad M=40 \%\end{array}$ & $\mid$\begin{tabular}{|l} 
Distance to \\
bikeway ${ }^{\mathrm{a}}$ Steep \\
hill to bikeway \\
Cross busy \\
street to \\
bikeway $^{\text {a }}$
\end{tabular} & GIS derived & $\mid \begin{array}{l}\text { Community } \\
\text { open space } \\
\text { Neighborhood }\end{array}$ & \begin{tabular}{|l} 
(use/non-use \\
of bikeway)
\end{tabular} & A, S & \begin{tabular}{|l} 
GIS steep \\
hill barrier \\
and greater \\
distance \\
associated \\
with non- \\
use of \\
bikeway
\end{tabular} \\
\hline
\end{tabular}

A, age; B, country of birth; C, children; E, education; Em, employed; F, female; GIS, geographic information system; I, income; M, male; S, sex.

${ }^{a}$ Environmental attribute variables derived from GIS databases.

Sallis et al. ${ }^{31}$ objectively plotted the addresses of respondents and all pay-for-use and free exercise facilities in local areas onto a grid map in order to assess the density of facilities near each participant. They found significant associations between the density of neighborhood, pay-for-use exercise facilities, and frequency of exercise, but no relationship with free facilities. In the case of free facilities, these may be aspects of communities (e.g., open grass-covered areas adjacent to schools) of which many people may not be aware, may not be aware that they could use, or may not believe that it would be appropriate to use.

Postal code areas were used by Bauman et al. ${ }^{30}$ to objectively identify place of residence of Australian adults. A respondent was categorized as a "coastal" resident if their postal code touched the coastline; those in all other postal code areas were categorized as "inland" residents. Adult respondents who lived at a coastal postal code area were $23 \%$ less likely to be inactive and $38 \%$ more likely to report vigorous exercise.

Troped et al. ${ }^{29}$ used geographic information systems (GIS) data to create three objective environmental variables (Table 2). The shortest-distance route from homes to an access point for a bikeway was inspected to determine if it intersected a busy street and whether this route crossed a steep slope grid. They compared these variables with self-reported perceptions of the same variables and found them to be correlated. Both self-report and GIS distance from the bikeway were associated with non-use of the bikeway. Self-report of having a busy street to cross and the GIS-measured steep-hills barrier was associated with bikeway non-use. 
The physical environment was also assessed using geographically derived data by Giles-Corti and Donovan. ${ }^{32}$ Spatial access (distance by road) to recreational facilities (both natural and built) was not found to be associated with activity. The authors also measured functional environment (whether the participant's street had footpaths and visible shops) and the appeal of the environment (volume of traffic and number of trees). These two variables were not associated with activity. However, unlike most of the other studies reviewed, a composite measure of all four variables demonstrated that a supportive physical environment had a significant association with the likelihood of being active.

\section{Pattern of findings}

The findings of the studies reviewed in Table 1 and Table 2 may be categorized within five sets of logical groupings: accessibility of facilities, opportunities for activity, weather, safety, and aesthetics. Safety, while not of itself an actual physical environment attribute, is plausibly related to factors in the physical environment (e.g., street lighting or the presence of sidewalks) that would affect perceptions of safety.

Findings of studies relating to accessibility of facilities, opportunities for physical activity, and the direction of these associations are summarized in Table 3. Findings pertaining to weather, items about safety while being active, and items regarding the aesthetic nature of the physical environment and the direction of these associations are summarized in Table 4.

Table 3. Patterns of findings on associations of accessibility of facilities and opportunities for activity, with physical activity

\begin{tabular}{|c|c|c|}
\hline Environmental variable & Studies (citation \#) & Associations \\
\hline \multicolumn{3}{|l|}{ Accessibility of facilities } \\
\hline A cycle path is accessible & 23 & + \\
\hline Busy street to cross & 29 & - \\
\hline Busy street to cross $^{\mathrm{a}}$ & 29 & 0 \\
\hline Negotiate steep hill & 29 & 0 \\
\hline Negotiate steep hill $^{\mathrm{a}}$ & 29 & - \\
\hline Access to facilities (local park) & 22 & + \\
\hline Facilities on frequently traveled route & 21 & + \\
\hline Density of pay and free facilities $^{\mathrm{a}}$ & 31 & + \\
\hline Neighborhood residential & 29 & - \\
\hline Number of convenient facilities & 19,25 & $0 / 0$ \\
\hline Lack of facilities & 15,19 & $-1-$ \\
\hline No facility nearby (women) & 16 & - \\
\hline Available facilities inadequate & 16 & - \\
\hline Access to built facilities $^{\mathrm{a}}$ & 32 & 0 \\
\hline Access to natural facilities $^{\mathrm{a}}$ & 32 & 0 \\
\hline Distance to bikeway & 29 & - \\
\hline Distance to bikeway $^{\mathrm{a}}$ & 29 & - \\
\hline Park or beach in walking distance & 23 & + \\
\hline Shops are in walking distance & 23 & + \\
\hline
\end{tabular}




\begin{tabular}{|l|l|l||}
\hline \multicolumn{1}{|c|}{ Environmental variable } & Studies (citation \#) & Associations \\
\hline Opportunities for activity & & \\
\hline Presence of sidewalks & 17,21 & $0 / 0$ \\
\hline Home equipment & $19,21,22,25,26$ & $+/+/ 0 / 0 /+$ \\
\hline Lack of equipment & 15,19 & $-/-$ \\
\hline Awareness of facilities & 24 & + \\
\hline Satisfaction with recreation facilities & 20 & + \\
\hline Neighborhood environment & 19,25 & $0 /+$ \\
\hline My area offers opportunities for physical activity & 28 & + \\
\hline Local clubs and others provide opportunities & 28 & + \\
\hline \hline Coastal residence & 30 & + \\
\hline Functional environment (footpath/shop) & 32 & 0 \\
\hline
\end{tabular}

+ , significant positive association found with physical activity; - , significant negative association found with physical activity; 0 , no association found with physical activity.

${ }^{a}$ Objectively assessed by geographic information system or other objective data.

Table 4. Patterns of findings on the associations of weather, safety, and aesthetic factors, with physical activity

\begin{tabular}{|l||l||l|}
\hline \multicolumn{1}{|c|}{ Environmental variable } & $\begin{array}{c}\text { Studies (citation } \\
\# \text { ) }\end{array}$ & Associations \\
\hline \hline Weather & & \\
\hline Poor weather & 18 & 0 \\
\hline Lack of good weather & 19 & 0 \\
\hline Safety & 22 & $0 / 0 / 0$ \\
\hline Footpaths are safe & $18,21,22$ & $0 / 0$ \\
\hline How safe to walk or jog alone in day & 17,18 & $0 / 0$ \\
\hline Lack a safe place to exercise & 17,18 & $0 /+$ \\
\hline High levels of crime & 17,18 & $0 / 0$ \\
\hline Unattended dogs & 17,18 & + \\
\hline Streetlights & 27 & $0 / 0$ \\
\hline How safe from crime is your neighborhood & 17,18 & \\
\hline Heavy traffic & \\
\hline Aesthetics & 23 \\
\hline Neighborhood friendly & 23 \\
\hline Pleasant near home & 23 \\
\hline Local area is attractive & + \\
\hline \hline
\end{tabular}




\begin{tabular}{|l|l|l|}
\hline \multicolumn{1}{|c|}{ Environmental variable } & $\begin{array}{c}\text { Studies (citation } \\
\#)\end{array}$ & Associations \\
\hline Enjoyable scenery & 17,18 & $+/+$ \\
\hline Hills & 17,18 & $0 /+$ \\
\hline Living environment & 20 & + \\
\hline \hline Appeal (traffic/trees) & 32 & 0 \\
\hline
\end{tabular}

+ , significant positive association found with physical activity; 0 , no association found with physical activity.

Overall, the majority of variables pertaining to accessibility of facilities have been found to be associated with physical activity. Specific opportunities for activity also exhibited significant associations. A relationship between home equipment and physical activity was found for most of the studies that assessed this variable. ${ }^{19,21,25,26}$ Many of the items used in the studies were worded quite similarly (e.g., "lack of facilities" and "no facility nearby"). It may be that the number of items presented in Table 3 could have been narrowed down. However, a consideration in doing so is the personal interpretation that each individual respondent may have applied to similar items. Some items are very specific; for example, "a park or beach is in walking distance," whereas "awareness of facilities" is more general and each respondent would be more likely to apply his or her idiosyncratic interpretation to what was being asked.

Few studies examined the relationship between the weather and physical activity (Table 4). Poor weather was examined as a barrier to physical activity in two studies, but neither found a significant association.

Few of the studies that used items pertaining to "safety" reported significant associations with physical activity. "Footpaths perceived as safe for walking" was related to being active, ${ }^{22}$ and "unattended dogs" was also related to being active, ${ }^{18}$ presumably because those who were more active were more likely to be aware of dogs. A study of determinants on physical activity in rural and urban women aged $>40$ years ${ }^{17}$ did not find significant results for any safety items in relation to physical activity. These investigators used neighborhood environment items developed by Sallis et al. ${ }^{21}$ in their study. They found that rural women were less likely to report sidewalks, streetlights, high crime rates, and lack of a safe place to exercise, compared to urban women. Using data from selected states in the 1996 Behavior Risk Factor Surveillance System, the Centers for Disease Control and Prevention ${ }^{27}$ in the United States found that people who perceived their neighborhood to be unsafe were more likely to be physically inactive. Significant associations emerged for aesthetics items, particularly those pertaining to the attractiveness and pleasantness of the local environment having enjoyable scenery and a friendly neighborhood.

\section{Discussion}

The associations of environmental attributes with physical activity have thus far been examined in a relatively limited set of studies. This review has examined the evidence for these relationships and highlighted relevant aspects of the measures that have been used in these studies. There were inherent difficulties, as some studies combined several physical environment items into an "overall" measure and compared that total score to physical activity behavior. Where it was possible to identify and separate the environmental items, we did so. By including only studies that examined relationship to physical activity behavior, we adhered to a quite strict criterion so that descriptive studies reporting (e.g., frequency of barrier items in a population) were not included.

In this field, many of the empirical studies have been only recently reported and the relevant theory is not yet well developed. The environmental attributes measured in the different studies are based in part on 
pragmatic insights and operationalized some broad theoretically derived constructs. The outcome variables used in the studies are also derived from different physical activity measures. A systematic review, providing a description of what the various studies have found and providing some preliminary classification of findings, should thus be helpful.

The labels we used in Table 3 and Table 4 are not proposed as definitive constructs. These labels portray "groupings" of environmental variables that we believe have some face validity. They potentially can be used as a descriptive jumping-off point for future research and would, we hope, be the basis for a more theoretical synthesis as the research literature in this field develops. Future research studies and theory development will undoubtedly produce a more refined and theoretically anchored set of constructs for characterizing environmental influences on different physical activity behaviors.

"Environmental influences" are currently identified within social cognitive and ecologic models of healthrelated behavior. However, the environmental component of these theories and models, while identified as important, has thus far been only broadly articulated. ${ }^{4,6,9} \mathrm{We}$ are not proposing here what could be seen as a "premature synthesis" of findings. Currently, even the most relevant theory does not provide sufficiently detailed conceptual tools for differentiating how the separate domains of environmental influences might impact on different physical activity behaviors.

Aspects of home environments were found to be associated with physical activity in cases where respondents reported having, for example, exercise videos and equipment. Aspects of the neighborhood environment were found to be associated with physical activity. The availability of, and access to, cycleways, footpaths, health clubs, and swimming pools were found to be associated with physical activity. ${ }^{16,21,22,28,29}$ Evidence appears to be accumulating for the importance of accessibility of facilities as an important environmental factor related to physical activity.

The development of objective measures of environmental factors is an important new direction for research. The use of GIS data to create physical environment variables on roads, hills, and street addresses and other variables $^{29,32}$ is showing some initial support for findings from self-report measures. Including GIS data in studies has considerable promise. GIS-derived measures can help to overcome some of the methodologic problems of reliance on self-reported environmental factors. ${ }^{33}$ Although the influence of the physical environment on activity behavior was found to be weak by Giles-Corti and Donovan, ${ }^{32}$ they found that accessibility to facilities was associated with their use. They concluded that a supportive environment would seem to be necessary, but may be insufficient on its own, to increase activity levels of populations. ${ }^{32}$

Public health strategy to promote physical activity is now strongly emphasizing the role of environmental influences to create opportunities and remove barriers to people being more active in their daily lives. ${ }^{1,5}$ The studies that we have reviewed are part of an expanding corpus of new research, seeking evidence that physical activity can be influenced by environmental attributes. While the importance of such influences would seem to be self-evident, the assertive pursuit of advocacy for physical activity opportunities must be strengthened by relevant empirical evidence. With one exception, ${ }^{14}$ the studies that we have reviewed present only cross-sectional associations of environmental attributes with physical activity behavior. Prospective and intervention studies are particularly needed so that conclusions can be drawn regarding the possible causal nature of these environment-behavior relationships.

Although "weather" items were found not to be strongly related to physical activity, it was difficult to assess their contributions because in most studies they were pooled with items related to other constructs. Studies need to incorporate the reported weather variable as a separate item. There may be some utility to wording that is more explicit about context (e.g., "it's too cold/hot to go walking"). Seasonal variation is not a fixed attribute of the environment, but a number of features-daylight hours, temperature, humidity, precipitation, 
and wind-may influence physical activity. We chose not to include studies of seasonal variation in our review. Two studies ${ }^{34,35}$ have reported that most activity was found to occur in the summer months and that this could vary by the particular activity and the individual.

The "aesthetics" or "neighborhood character" variables show promise, with significant associations emerging in the four studies that included them. Further studies are needed, perhaps including more variations on this dimension and examining it in relation to different types of activity (e.g., walking and sport participation). It is likely that there will be different environmental influences on different types of activity. ${ }^{6}$

Findings for "safety" items, somewhat surprisingly, demonstrated few associations with physical activity. A possible explanation for the lack of association with safety is that for people who are physically active in places other than their neighborhood, neighborhood safety may not be an issue. Perhaps safety would seem to be applicable only to outdoor activity and needs to be applied in studies that only measure specific outdoor activities, not total activity. At first glance, unattended dogs being positively related to activity seems counterintuitive. On further consideration, perhaps it is only those people who are active and thus out in the street who know about the unattended dogs. A significant association was found between perceived safety from crime and physical activity behavior by the Centers for Disease Control and Prevention. ${ }^{27}$ Safety may also need to be separated into further categories. These could include perceived safety from crime or safety from injury (e.g., lack of footpaths). Future research should explore possible gender differences in perceived safety for exercising.

When a number of physical environment variables are combined (e.g., in a "total neighborhood" measure), possible associations can potentially be obscured. In one study, ${ }^{21}$ the variables included safety and character of the local neighborhood in a single scale and did not find a significant association with physical activity.

Twelve of the studies reviewed operationalized one or more theoretically derived constructs. Most were based on social cognitive theory or ecologic models. A common factor in these models is that they incorporate explicit environmental constructs. Overall, there would seem to be some evidence that studies based on theoretical underpinnings that are inclusive of environmental influence on physical activity would be advantageous. The origin of the physical environment scales and factors measured are sometimes not explicitly explained in the studies. Some report that the items were based on a particular theory, without any description of how they were developed. Others state that the items were based on qualitative studies or on measures reported in previous studies.

A number of the significant findings explored relationships to vigorous activity, with relatively fewer findings on moderate-intensity activities or walking. These differences contributed to the difficulty of reviewing this literature. Diverse behaviors and environments were studied, and the studies themselves used various ways of measuring these associations. Behavior-specific items need to be developed that addressand assess - attributes specific to a particular behavior in a particular context or setting. ${ }^{4}$ Prospective studies of environmental factors as predictors of physical activity change are needed (we identified only one such study ${ }^{14}$ ), as are environmentally focused intervention studies. ${ }^{36}$ If particular environmental attributes identified in cross-sectional studies are to be advocated in order to influence policy changes and large-scale environmental innovations, evidence from intervention studies is crucial. ${ }^{3,37}$ In light of the available evidence, we would conclude that research on environmental influences has considerable promise for the purpose of identifying significant and potentially modifiable influences on physical activity behavior. 


\section{References}

1. U.S. Department of Health and Human Services, Physical activity and health a report of the Surgeon General, U.S. Department of Health and Human Services. Centers for Disease Control and Prevention, National Center for Chronic Disease Prevention and Health Promotion, Atlanta, GA (1996).

2. R.K Dishman, J.F Sallis, Determinants and interventions for physical activity and exercise, C Bouchard, R.J Shephard, T Stephens (Eds.), Physical activity, fitness, and health, international proceedings and consensus statement, Human Kinetics, Champaign, IL (1994), pp. 214-238.

3. J.F Sallis, N Owen, Physical activity and behavioral medicine, Sage Publications Inc, Thousand Oaks, CA (1999).

4. J.F Sallis, N Owen, Ecological models, K Glanz, F.M Lewis, B.K Rimer (Eds.), Health behavior and health education theory, research and practice (2nd ed.), Jossey-Bass, San Francisco (1997), pp. 403-424.

5. J.F Sallis, A Bauman, M Pratt, Environmental and policy interventions to promote physical activity, Am J Prev Med, 15 (1998), pp. 379-397.

6. N Owen, E Leslie, J Salmon, M.J Fotheringham, Environmental determinants of physical activity and sedentary behaviour, Exerc Sport Sci Rev, 28 (2000), pp. 153-158.

7. G Godin, Social-cognitive models, R.K Dishman (Ed.), Advances in exercise adherence, Human Kinetics, Champaign, IL (1994), pp. 113-136.

8. A Bandura, Social foundations of thought and action, Prentice-Hall, Englewood Cliffs, NJ (1986).

9. J.F Sallis, M.F Hovell, Determinants of exercise behaviour, J.O Holloszy, K.B Pandolf (Eds.), Exercise and Sport Sciences Reviews, Williams \& Wilkins, Baltimore, MD (1990), pp. 307-330.

10. D Stokols, Translating social ecological theory into guidelines for health promotion, Am J Health Promot, 10 (1996), pp. 282-298.

11. K.R McLeroy, D Bibeau, A Steckler, K Glanz, An ecological perspective on health promotion programs, Health Educ Q, 15 (1988), pp. 351-377.

12. R.G Barker, Ecological psychology, Stanford University Press, Stanford, CA (1968).

13. A.C King, R.W Jeffery, F Fridinger, S Provence, S.A Hedlund, K Spangler, Environmental and policy approaches to cardiovascular disease prevention through physical activity issues and opportunities, Health Educ Q, 22 (1995), pp. 499-511.

14. J.F Sallis, M.F Hovell, C.R Hofstetter, Predictors of adoption and maintenance of vigorous physical activity in men and women, Prev Med, 21 (1992), pp. 237-251.

15. B Sternfeld, B.E Ainsworth, C.P Quesenberry, Physical activity patterns in a diverse population of women, Prev Med, 28 (1999), pp. 313-323. 
16. S.M Shaw, A Bonen, J.F McCabe, Do more constraints mean less leisure? Examining the relationship between constraints and participation, J Leisure Res, 23 (1991), pp. 286-300.

17. S Wilcox, C Castro, A.C King, R.A Houseman, R Brownson, Determinants of leisure time physical activity in rural compared with urban older and ethnically diverse women in the United States, J Epidemiol Community Health, 54 (2000), pp. 667-672.

18. A.C King, C Castro, S Wilcox, A.A Eyler, J.F Sallis, R Brownson, Personal and environmental factors associated with physical inactivity among different racial-ethnic groups of U.S. middle-aged and older-aged women, Health Psychol, 19 (2000), pp. 354-364.

19. J.F Sallis, M.F Hovell, C.R Hofstetter et al., A multivariate study of determinants of vigorous exercise in a community sample, Prev Med, 18 (1989), pp. 20-34.

20. C MacDougall, R Cooke, N Owen, K Willson, A Bauman, Relating physical activity to health status, social connections and community facilities, Aust N Z J Public Health, 21 (1997), pp. 631637.

21. J.F Sallis, M.F Johnson, K.J Calfas, S Caparosa, J.F Nichols, Assessing perceived physical environmental variables that may influence physical activity, Res Q Exerc Sport, 68 (1997), pp. 345-351.

22. M.L Booth, N Owen, A Bauman, O Clavisi, E Leslie, Social-cognitive and perceived environmental influences associated with physical activity in older Australians, Prev Med, 31 (2000), pp. $15-22$.

23. K Ball, A Bauman, E Leslie, N Owen, Perceived environmental and social influences on walking for exercise in Australian adults, Prev Med, 33 (2001), pp. 434-440.

24. E Leslie, N Owen, J Salmon, A Bauman, J.F Sallis, S.K Lo, Insufficiently active Australian college students perceived personal, social, and environmental influences, Prev Med, 28 (1999), pp. 20-27.

25. M.F Hovell, J.F Sallis, C.R Hofstetter, V.M Spry, P Faucher, C.J Caspersen, Identifying correlates of walking for exercise an epidemiologic prerequisite for physical activity promotion, Prev Med, 18 (1989), pp. 856-866.

26. J.M Jakicic, R.R Wing, B.A Butler, R.W Jeffery, The relationship between presence of exercise equipment in the home and physical activity level, Am J Health Promot, 11 (1997), pp. 363365.

27. Centers for Disease Control and Prevention, Neighborhood safety and the prevalence of physical activity—selected states, 1996. MMWR Morb Mort Wkly Rep, 47 (1999), pp. 143-146.

28. T Stahl, A Rutten, D Nutbeam et al., The importance of the social environment for physically active lifestyle_results from an international study, Soc Sci Med, 52 (2001), pp. 1-10.

29. P.J Troped, R.P Saunders, R.R Pate, B Reininger, J.R Ureda, S.J Thompson, Associations between selfreported and objective physical environment factors and use of a community rail-trail, Prev Med, 32 (2001), pp. 191-200. 
30. A Bauman, B Smith, L Stoker, B Bellew, M.L Booth, Geographical influences upon physical activity participation evidence of a "coastal effect", Aust N Z J Public Health, 23 (1999), pp. $322-$ 324.

31. J.F Sallis, M.F Hovell, C.R Hofstetter et al., Distance between homes and exercise related facilities related to frequency of exercise among San Diego residents, Public Health Rep, 105 (1990), pp. 179-185.

32. Giles-Corti B, Donovan RJ. The relative influence of individual, social and physical environment determinants of physical activity. Soc Sci Med. In press.

33. Bauman A, Sallis JF, Owen N. Environmental and policy measurement in physical activity research. In: Welk G, Dale D, eds. Physical activity assessment for health-related research. Champaign, IL: Human Kinetics. In press.

34. D.G Uitenbroek, Seasonal variation in leisure time physical activity, Med Sci Sport Exerc, 25 (1993), pp. 755-760.

35. C.E Matthews, P.S Freedson, J.R Hebert et al., Seasonal variation in household, occupational, and leisure time physical activity longitudinal analysis from the seasonal variation of blood cholesterol study, Am J Epidemiol, 153 (2001), pp. 172-183.

36. J.M Linenger, C.V Chesson, D.S Nice, Physical fitness gains following simple environmental change, Am J Prev Med, 7 (1991), pp. 298-310.

37. J.F Sallis, N Owen, M.J Fotheringham, Behavioral epidemiologya systematic framework to classify phases of research on health promotion and disease prevention, Ann Behav Med, 22 (2000), pp. 1-6. 